\title{
EVALUASI PENGGUNAAN ANTIBIOTIK PADA KASUS DEMAM TIFOID DI INSTALASI RAWAT INAP RSUD ABDUL WAHAB SJAHRANIE SAMARINDA
}

\author{
Fitri Athaya, Adam M. Ramadhan, Muhammad Amir Masruhim \\ Fakultas Farmasi Universitas Mulawarman, Samarinda, Kalimantan Timur \\ *Email: fitri.athaya@ymail.com
}

\begin{abstract}
ABSTRAK
Demam tifoid merupakan penyakit infeksi yang disebabkan oleh kuman Salmonella typhi. Hingga saat ini demam tifoid masih menjadi masalah kesehatan di negara-negara tropis termasuk di Indonesia. Antibiotik merupakan obat utama yang digunakan untuk mengobati penyakit ini, penggunaan antibiotik yang tidak tepat menyebabkan obat tidak efektif dan memberikan dampak buruk bagi pasien. Penelitian ini bertujuan untuk mengetahui gambaran dan mengevaluasi penggunaan antibiotik pada pasien demam tifoid di Instalasi Rawat Inap RSUD Abdul Wahab Sjahranie Samarinda tahun 2015. Penelitian ini merupakan jenis penelitian non eksperimental dengan pengumpulan data secara retrospektif dan dianalisis secara deskriptif. Data diambil pada periode Januari-September 2015, dan didapatkan data sebanyak 56 kasus. Hasil penelitian berdasarkan umur menunjukkan bahwa pasien demam tifoid paling banyak berusia 5-24 tahun sebanyak 34 pasien $(61 \%)$, berdasarkan jenis kelamin didaptakan hasil laki-laki lebih banyak daripada perempuan yaitu sebanyak 34 pasien $(60,71 \%)$. Hasil dari penggunaan antibiotik didapatkan penggunaan terbanyak adalah antibiotik sefrikason sebanyak 24 pasien (42\%). Dari hasil evaluasi diketahui bahwa 100\% tepat indikasi, $100 \%$ tepat pasien, $91 \%$ tepat obat, dan $80 \%$ tepat dosis.
\end{abstract}

Kata Kunci : Demam tifoid, Antibiotik

\begin{abstract}
Typhoid fever is an infection disease caused by the bacteria Salmonella typhi. Until now typhoid fever remains a health problem in tropical countries, including Indonesia. Antibiotics are the main drugs used to treat this disease, an inappropriate use of antibiotics cause the drug to be ineffective and detrimental to the patient. This study aims to describe and evaluate the use of antibiotics in patients with typhoid fever in RSUD Abdul Wahab Sjaharanie Samarinda 2015. This study is non-experimental study with retrospective data collection and analyzed descriptively. Sampling with purposive sampling, the data obtained as many as 56 cases. The results based on age shows that most patients with typhoid fever aged 5-14 years as many as 26 patients (46.42\%), based on gender didaptakan result more man than women as many as 34 patients $(60.71 \%)$. And the results obtained from the use antibioitik is the highest use of antibiotics sefrikason as many as 24 patients $(42 \%)$. From the results of the evaluation it was known that $100 \%$ appropiate indications, $100 \%$ appropiate patient, $91 \%$ appropiate drug and $80 \%$ appropiate dose.
\end{abstract}

Keywords: Thypoid fever, antibiotic 


\section{Pendahuluan}

Demam tifoid adalah penyakit akibat infeksi bakteri S. typhii. Demam tifoid masih merupakan masalah kesehatan di beberapa negara yang timbul secara endemik dan ditemukan sepanjang tahun. Penyakit ini banyak dijumpai diberbagai negara berkembang yang terutama terletak di daerah tropis dan subtropis. Demam tiofid merupakan salah satu penyakit menular yang berkaitan erat dengan kebersihan perorangan yang kurang baik, keadaan lingkungan yang kurang baik (misalnya penyediaan air bersih yang kurang memadai, pembuangan sampah dan kotoran manusia yang kurang memenuhi syarat kesehatan, pengawasan makanan dan minuman yang belum sempurna), serta fasilitas kesehatan yang tidak terjangkau oleh sebagian masyarakat (Mansjoer, 2000).

Menurut data World Health Organization (WHO) tahun 2003, terdapat 17 juta kasus demam tifoid di seluruh dunia dengan angka kematian mencapai 600.000 kasus tiap tahunnya. Kasus demam tifoid telah tercantum dalam Undang-undang nomer 6 tahun 1962 tentang wabah. Angka kejadian demam tifoid di Indonesia sebesar 1000/100.000 populasi pertahun. Berdasarkan Profil Kesehatan Indonesia tahun 2010, dari 10 penyakit terbanyak pada pasien rawat inap di rumah sakit di Indonesia demam tifoid menempati urutan ke-3 dengan jumlah kasus mencapai 41.081 pasien dan 274 diantaranya meninggal dunia. Menurut data Hasil Riset Dasar Kesehatan (RISKESDAS) tahun 2007, demam tifoid menyebabkan 1,6\% kematian penduduk Indonesia untuk semua umur. Penyakit ini dapat menyerang banyak orang dari anak-anak maupun orang dewasa yang berumur 3 tahun sampai 19 tahun.

Tata laksana pada demam tifoid yang masih sering digunakan adalah istirahat, perawatan diet, terapi penunjang serta pemberian antibiotik. Antibiotik merupakan senyawa kimia yang dihasilkan oleh suatu mikroorganisme, yang dapat membunuh mikroorganisme lain. Pada dasarnya, suatu infeksi lazimnya dapat ditangani secara berhasil oleh sistem pertahanan tubuh, namun adakalanya sistem ini perlu ditunjang oleh penggunaan antibiotik, meskipun sangat disadari bahwa banyak antibiotik telah mengalami penyalahgunaan.

Penggunaan antibiotik yang tidak benar dapat menyebabkan resistensi bakteri terhadap antibiotik yang digunakan. Selain itu, penggunaan yang tidak bijak dapat meningkatkan interaksi dan efek samping. Efek samping penggunaan antibiotik yang tidak sesuai dengan standar terapi dapat terjadi, ditambah lagi kelangkaan informasi yang obyektif mengenai ketidaktepatan pemakaian. Di rumah sakit, dimana penggunaan antibiotik biasanya dalam jumlah besar, resistensi bakteri terhadap beberapa antibiotik sering terjadi dan menjadi masalah utama dalam upaya perawatan pasien.

\section{METODE PENELITIAN}

\section{JENIS PENELITIAN}

Penelitian ini termasuk jenis penelitian non eksperimental, dilakukan secara observasional yang datanya diambil secara retrospektif dan dianalisis secara deskriptif.

\section{BAHAN}

Kartu rekam medik pasien demam tifoid yang memenuhi kriteria inklusi, yang diperoleh data 56 pasien yang terdapat di RSUD Abdul Wahab Sjahranie Samarinda.

\section{PERALATAN}

Lembar kerja pemindahan data dan alat tulis.

\section{PROSEDUR}

Penelitian diawali dengan observasi pasien demam tifoid. Sampel ditentukan dari 
populasi pasien yang memenuhi kriteria inklusi. Kriteria inklusi sampel yaitu :

a. Pasien demam tifoid yang dirawat inap dengan diagnosa akhir demam tifoid yang memiliki data rekam medik lengkap dalam hal data penderita, dan pemberian terapi antibiotik yang meliputi jenis antibiotik, rute pemberian dan lama pemakaian.

b. Pasien yang berumur 5-60 tahun

Penelitian ini dilakukan dengan pengambilan data secara retrospektif. Pengumpulan data dilakukan dengan mencatat beberapa parameter meliputi nomor rekam medik, umur, jenis kelamin, diagnosa, keluhan, riwayat penyakit dan penyakit penyerta. Data penelitian dianalisis secara deskriptif dan dibuat dalam betuk tabulasi dan persen.

\section{HASIL DAN PEMBAHASAN}

\section{Karakteristik Umur dan Jenis Kelamin}

Bedasarkan karakteristik umur pasien demam tifoid di Instalasi Rawat Inap RSUD Abdul Wahab Sjahranie Samarinda didapatkan presentasi sebagai berikut :

Tabel 1. Karakteristik Pasien Demam Tifoid Berdasarkan Umur

\begin{tabular}{ccc}
\hline $\begin{array}{c}\text { Karakteristik } \\
\text { Umur }\end{array}$ & Jumlah & Persentase \\
\hline $5-24$ & 34 & $61 \%$ \\
$25-44$ & 16 & $28 \%$ \\
$45-60$ & 6 & $11 \%$ \\
\hline
\end{tabular}

Dari penelitian diketahui bahwa penderita demam yang menjalani rawat inap RSUD Abdul Wahab Sjahranie Samarinda tahun 2015, lebih banyak dijumpai pada pasien yang berumur 5-24 tahun. Insidensi penderita demam tifoid di daerah endemik lebih banyak ditemukan pada anank-anak, pada orang dewasa infeksi ringan sering dialami tetapi dapat sembuh dengan sendirinya (Juwono, 2004). Dari hasil penelitian yang didapat terbukti bahwa penderita demam tifoid terbanyak terdapat pada umur 5-24 tahun sebesar $61 \%$.

Tabel 2. Karakteristik Jenis Kelamin

\begin{tabular}{ccc}
\hline Karakteristik & Jumlah & Persentase \\
Jenis Kelamin & 34 & $60 \%$ \\
Laki-laki & 22 & $40 \%$ \\
Perempuan & & \\
\hline
\end{tabular}

Karateristik pasien berdasarkan jenis kelamin dari 56 pasien diketahui bahwa penderita demam tifoid lebih banyak jenis kelamin laki-laki dibandingkan perempuan karena laki-laki lebih sering melakukan aktivitas diluar rumah dibandingkan perempuan. Selain itu laki-laki juga jarang menjaga ke higienisan seperti jarang mencuci tangan, seringnya jajan dipinggir jalan. Hal ini mempengaruhi lebih besarnya terkena infeksi kuman Salmmonella thyposa. 


\section{Gambaran Penggunaan Antibiotik}

Tabel 3. Penggunaan Antibiotik Pasien Demam Tifoid

\begin{tabular}{ccccc}
\hline $\begin{array}{c}\text { Golongan } \\
\text { Antibiotik }\end{array}$ & Nama & Rute & Jumlah & Persentase \\
\hline \multirow{3}{*}{ Sefalosforin } & Sefriakson & I.V & 24 & $42 \%$ \\
& Sefiksim & Oral & 9 & $16 \%$ \\
& Sefotaksim & I.V & 5 & $8,9 \%$ \\
\hline Floroquinolon & Siprofloksasin & I.V & 1 & $1,7 \%$ \\
& Levofloksasin & I.V & 1 & $1,7 \%$ \\
\hline Penisilin & Amoksisilin & I.V & 3 & $5,3 \%$ \\
& & Oral & 3 & $5,3 \%$ \\
\hline Kloramfenikol & Kloramfenikol & Oral & 2 & $3,5 \%$ \\
& Tiamfenikol & Oral & 4 & $7,1 \%$ \\
\hline
\end{tabular}

Hasil penelitian berkaitan dengan jumlah serta presentase jenis dan golongan antibiotik pada pasien demam tifoid yang berada di Instalasi rawat inap RSUD Abdul Wahab Sjahranie Samarinda presentase terbanyak didapatkan antibiotik golongan sefalosforin yaitu antibiotik sefriakson sebesar $42 \%$ kemudian antibioitk sefiksim $16 \%$, dan antibioitik sefotaksim sebesar $8,9 \%$. Untuk golongan floroquinolon antibiotik yang digunakan adalah siprofloksasin dan levofloksasin didapatkan hasil yang sama yaitu sebesar 1,7\%. Antibiotik golongan penisilin yaitu amoksisilin sebanyak 5,3\% dan golongan kloramfenikol untuk antibioitik kloramfenikol sebanyak 3,5\% dan tiamfenikol $7,1 \%$.

Sefriakson dianggap sebagai obat yang poten dan efektif untuk mengobati demam tifoid jangka pendek. Sifat yang menguntungkan dari obat ini adalah secara selektif dan merusak struktur kuman dan tidak mengganngu sel tubuh manusia, mempunyai spektrum luas, penetrasi jaringan cukup baik, dan resistensi kuman masih terbatas. Menurut Lim $\mathrm{Hu}$ Yoe peneliti Malaysia, pengobatan dengan seftriakson hanya membutuhkan 10 hari lama rawat inap di rumah sakit dibandingkan dengan kloramfenikol yaitu selama 21 hari.

Tabel 5. Pemakaian Antibiotik Kombinasi

\begin{tabular}{cccc}
\hline Golongan & Antibiotik & Jumlah & Persen \\
\hline $\begin{array}{c}\text { Sefalosforin } \\
\text { Generasi ketiga }\end{array}$ & $\begin{array}{c}\text { Sefriaxone }+ \\
\text { Sefixime }\end{array}$ & 3 & $5,3 \%$ \\
$\begin{array}{c}\text { Sefalosforin } \\
\text { gererasi ketiga+ } \\
\text { penisilin }\end{array}$ & $\begin{array}{c}\text { Sefriakson }+ \\
\text { amoksisilin }\end{array}$ & 1 & $1,7 \%$ \\
\hline
\end{tabular}

Terapi kombinasi digunakan pada kasus-kasus dan beberapa tujuan tertentu seperti mencegah resistensi bakteri terhadap antibiotik, menambah keefektifan antibiotik yang mekanisme kerjanya saling bersinergi, menangani kemungkinan adanya infeksi yang 
disebabkan oleh lebih dari satu jenis bakteri dan digunakan untuk menangani suatu kasus infeksi yang berat (Murray, 2009). Dari hasil penelitian didapatkan terdapat 4 kasus yang menggunakan antibioitk kombinasi yaitu kombinasi sefriaxone dengan sefixime $(5,3 \%)$ dan sefriakson sedengan amoksisilin $(1,7 \%)$

\section{Evaluasi Penggunaan Obat}

Parameter yang digunakan adalah yaitu tepat indikasi, tepat pasien, dan tepat obat.

\section{a. Tepat Indikasi}

Tepat indikasi berkaitan dengan perlu tidaknya pemberian antibiotik sesuai dengan diagnosa yang ditegakkan. Kesalahan dalam penegakan diagnosis akan berpengaruh pada kesalahan pemilihan obat sehingga menyebabkan obat yang diberikan tidak akan memberikan efek yang diinginkan. Ketepatan indikasi penggunaan antibiotik pada 56 pasien demam tifoid di Instalasi Rawat Inap RSUD Abdul Wahab Sjahranie Samarinda hasilnya tepat indikasi karena seluruh pasien demam tifoid mendapat terapi dengan antibiotik. Hasil penelitian sesuai dengan standar Depkes RI tahun 2006, antibiotik segera diberikan bila diagnosis klinis demam tifoid telah ditegakkan. Antibiotik digunakan untuk pengobatan demam tifoid karena patofisiologi infeksi Salmonella typhi berhubungan dengan keadaan bakterimia (Merdjani, 2008).

\section{b. Tepat Pasien}

Tepat pasien dievaluasi dari ketepatan pemberian antibiotik yang disesuaikan dengan kondisi fisiologis dan patologis pasien, tidak adanya kontra indikasi penggunaan obat dengan pasien dan tidak ada riwayat alergi. Evaluasi ketepatan pasien didasarkan atas hasil laboratorium SGOT/SGPT untuk fungsi hati. Peringatan bagi pasien dengan penurunan fungsi hati yang berat diterapkan terhadap pasien yang mendapat terapi dengan antibiotik sefriakson, siprifloksasin, dan levofloksasin (BNF, 2009). Penelitian pada pasien demam tifoid di instalasi rawat inap RSUD Abdul Wahab Sjaharanie Samarinda terdapat 56 pasien memiliki nilai SGOT/SGPT normal. Sehingga hasil penelitian menunjukkan 56 pasien $(100 \%)$ tepat pasien karena pemnerian obat sesuia dan tidak kontraindikasi dengan pasien.

\section{c. Tepat Obat}

Obat dinyatakan tepat obat didasarkan pada pertimbangan manfaat dan keamanan obat tersebut, pemilihan obat merupakan upaya terapi yang diambil setelah diagnosis ditegakkan dengan benar. Evaluasi tepat obat disesuaikan dengan guidlene WHO 2003. Menurut guidlene WHO 2003, antibiotik yang digunakan adalah kloramfenikol, amoksisilin, kotrimoksasol, sefriakson,sefiksim, siprofloksasin, dan levofloksasin.

Antibiotik yang digunakan di Instalasi Raway Inap RSUD Abdul Wahab Sjahranie Samarinda adalah golongan sefalosforin generas ketiga, floroquinolon, penisilin, dan kloramfenikol.

Hasil penelitian menunjukkan ada 5 penggunaan antibiotik pada pasien demam tifoid di Instalasi rawat inap RSUD Abdul Wahab Sjahranie Samarinda yang tidak sesuai dengan dengan guidlene WHO 2003. Antibiotik tersebut adalah tiamfenikol dan kombinasi sefriakson-amoksisilin.

Tabel 6. Ketidaktepatan Penggunaan Obat

\begin{tabular}{cc}
\hline Antibiotik & Jumlah \\
\hline Tiamfenikol & 4 \\
Sefriakson+amoksisilin & 1 \\
\hline
\end{tabular}


Antibiotik yang paling banyak digunakan di Instalasi Rawat Inap RSUD Abdul Wahab Sjahranie adalah dari golongan sefalosporin generasi ketiga yaitu seftriakson, sedangkan menurut guidline WHO (2003) antibiotik seftriakson bukan merupakan antibiotik yang digunakan pada pasien demam tifoid dewasa. Namun dari penelitian menunjukkan bahwa penggunaan seftriakson pada pasien demam tifoid dapat menurunkan suhu badan penderita dalam waktu singkat dibanding antibiotik kloramfenikol sehingga efektif bila dipakai. Selain itu tidak ada laporan mengenai resistensi seftriakson dalam mengobati demam tifoid (Hammad et al, 2011). Sampai saat ini golongan sefalosporin generasi ketiga yang terbukti efektif untuk mengobati demam tifoid adalah seftriakson (Widodo, 2008). Seftriakson dianggap sebagai antibiotik yang efektif dan poten untuk mengobati penyakit demam tifoid dalam jangka waktu pendek. Obat ini mempunyai sifat menguntungkan yaitu dapat merusak struktur bakteri tanpa mengganggu sel tubuh manusia, spektrumnya luas, dan resistensinya terhadap bakteri masih terbatas (Musnelina dkk, 2004). Golongan sefalosporin generasi ketiga lainnya yang digunakan untuk pengobatan demam tifoid adalah sefotaksim, dan sefiksim pada pasien demam tifoid digunakan jika ada resistensi terhadap antibiotik quinolon. Sefotaksim digunakan pada pasien demam tifoid berat yang resiten terhadap quinolon (WHO, 2003). Sefotaksim dan seftriakson efektif untuk pengobatan bakteri gram negatif seperti S.typhi (Gunawan, 2007). Alasan ini yang memungkinkan seftriakson dan sefotaksim digunakan di RSUD Abdul Wahab Sjahranie Samarinda. Kombinasi antibiotik untuk sefriakson+amoksisilin, tidak diperlukan dikarenakan dapat meningkatkan toksisitas dan biaya.

Hasil yang didapat untuk ketidak tepatan obat pada pasien demam tifoid di Instalasi rawat Inap RSUD Abdul Wahab Sjahranie Samarinda adalah dari 56 pasien, 5 pasien (9\%) menerima antibiotik tidak tepat karena penggunaan antibiotik tidak sesui dengan guidline WHO (2003) dan 51 pasien (91\%) menerima antibiotk dengan tepat.

\section{d. Tepat Dosis}

Tepat dosis merupakan ketepatan pemberian dosis obat sesuia dengan standar pengobatan yang oleh Depkes RI 2006. Dosis diberikan tergantung dari faktor usia, berat badan, jenis kelamin, keparahan penyakit dan keadaan pasien.

Evaluasi ketepatan dosis dinilai berdasarkan standar yang ditetapkan oleh Depkes RI 2006. Dosis suatu obat snagat berperan penting karena menetukan obat tersebut dapat memberikan efek optimal atau tidak.

Tabel 7. Tabel Ketidaktepatan Dosis

\begin{tabular}{|c|c|c|c|}
\hline $\begin{array}{c}\text { Dosis Antibiotik } \\
\text { Standar (Depkes } \\
\text { RI, 2006) }\end{array}$ & Dosis Pemakaian & Jumlah & Presentase \\
\hline $\begin{array}{c}\text { Sefriakson IV 2- } \\
\text { 4mg/hari } \\
\text { (5 hari) }\end{array}$ & $\begin{array}{c}\text { Sefriakson 1g/hari } \\
\text { (2hari-3 hari) } \\
\text { Sefriakson 2g/hari } \\
\text { (3hari-4 hari }\end{array}$ & 6 & $7 \%$ \\
\hline $\begin{array}{c}\text { Siprofloksasin IV } \\
\text { 2x500 mg } \\
\text { 1minggu }\end{array}$ & $\begin{array}{c}\text { Siprofloksasin } \\
\text { 2x200mg/hari } \\
\text { (3hari,5hari) }\end{array}$ & 1 & 1,7 \\
\hline
\end{tabular}


Berdasarkan Tabel 7, hasil penelitian dari 56 pasien, sebanyak 45 pasien $(80 \%)$ tepat dosis dan 11 pasien (20\%) tidak tepat dosis. Pengobatan demam tifoid dengan antibiotik yang tidak tepat dosis disebabkan karena dosis yang diberikan kurang dan durasi antibiotik yang digunakan kurang dari dosis standar. Berdasarkan stadar Depkes RI 2006, sefriakson diberikan dengan dosis $2-4 \mathrm{mg} /$ hari namun pada pemberian dosis antibiotik untuk pasien demam tifoid di Istalasi Rawat Inap RSUD Abdul Wahab Sjharanie Samarinda pasien diberikan dosis 1g/hari dan 2g/hari dengan lama pemberian 3-4 hari. Pemberian antibiotik dalam dosis kurang atau lebih dapat membahayakan pasien karena dapat menyebabkan keracunan dan pemborosan. Semakin besar dosis yang diberikan untuk pasien dalam jangka waktu lama atau sering menggunakan antibiotik tertentu, maka pasien tersebut akan kebal bila dosis antibiotik yang diberikan kecil untuk penyakit ringan (Tjay dan Rahardja,2002). Durasi penggunaan antibiotik yang tidak tepat dapat menyebabkan bakteri resistensi terhadap antibiotik tersebut.

\section{KESIMPULAN}

Berdasarkan hasil penelitian pada 56 pasien demam tifoid yang menjalani rawat inap di Instalasi Rawat Inap RSUD Abdul Wahab Sjahranie Samarinda, dapat disimpulkan:

1. Antibiotik yang digunakan adalah seftriakson (42\%), sefiksim (16\%), sefotaksim $(8,9 \%)$, siprofloksasin $(1,7 \%)$, levofloksasin $(1,7 \%)$, amoksisilin $(5,3 \%)$, kloramfenikol $(3,5 \%)$, tiamfenikol $(7,1 \%)$.

2. Pada evaluasi penggunaan antibiotik berdasarkan (Tepat indikasi, Tepat pasien, Tepat obat), pasien demam tifoid yang tepat indikasi sebanyak $100 \%$, tepat pasien sebanyak $100 \%$, tepat obat sebanyak $91 \%$ dan tepat dosis $80 \%$.

\section{DAFTAR PUSTAKA}

Masjoer Arief, dkk. 2000. Kapita Selekta Kedokteran Edisi Ketiga Jilid 2. Media Aesculapius Fakultas Kedokteran UI : Jakarta.

World Healt Organization. 2007. Background Document: The Diagnosis,Treatment and Prevention Of Typhoid Fever, Geneva, Switzerland

Juwono, R., 2004, Ilmu Penyakit Dalam, Jilid 1, Fakultas Kedokteran UI, Jakarta.

Tjay, H.T. \& Rahardja, K., 2007,Obat-Obat Penting, Khasiat, Penggunaannya, dan EfekEfek Sampingnya, Edisi ke V, Cetakan ke-2, Hal 63-83, Penerbit PT Elex Media Komputindo, Jakarta.

Gunawan, S.G., 2007, Farmakologi dan Terapi, Edisi Kelima, Penerbit Departemen Farmakologi dan Therapeutik FKUI, Jakarta.

WHO, 2003, Background Document : The Diagnosis,Treatment and Prevention of Typhoid Fever. World Health Organization, 9-24.

Musnelina, L., Afdhal, A.F., Gani, A., Andayani, P., 2004, Pola Pemberian Antibiotik Pengobatan Demam Tifoid Anak di Rumah Sakit Fatmawati Jakarta Tahun 20012002, Makara Kesehatan, 8 (2), 59-64.

Merdjani, A., \& Syoeib, A., 2008, Buku Ajar Infeksi dan Pediatri Tropis, Edisi Kedua, Bagian Ilmu Kesehatan Anak FKUI, Jakarta

BNF, 2009, $49^{\text {th }}$ ed, British National Formulary, United Kingdom, BMJ Group and RPS Publishing

Hammad, O. M., Hifnawy, T., Omran, D., Tantawi, M. A. \& Girgis, N. I., 2011, Ceftriaxone versus Chloramphenicol for Treatment of Acute Typhoid Fever, Life Science Journal, 8(2), 100-105. 